\title{
Design and Validation of a Questionnaire to Analyze University
}

\section{Dropout-CADES}

\author{
Pablo Díaz \& Alexis Tejedor De León ${ }^{2 *}$ \\ 1 Master's Program in Educational Psychology, University Extension in Veraguas, Universidad \\ Especializada de las Américas, Santiago, Veraguas, Panama \\ ${ }^{2}$ Department of Materials and Metallurgy, Regional Center of Veraguas, Universidad Tecnológica de \\ Panamá, Santiago, Veraguas, Panama \\ *Alexis Tejedor De León, E-mail: alexis.tejedor@utp.ac.pa
}

\begin{abstract}
Educational institutions and, in particular, universities must establish a clear vision and mission regarding the training that every social professional will demand. The university has always played the role of a selection filter for students, but the fact that a significant number of college students are abandoning their programs without having completed their course of studies, is a specific symptom of an educational crisis that is occurring within them. For this reason, the present study aimed to design and validate a key tool to establish the causes, whether endogenous or exogenous as to why students leave college without having completed their studies. The ad hoc questionnaire design took into consideration the proposals of a several research studies and the instrument developed was validated in a sample of 70 unit dropout cohorts for the years 2013-2014 and 2015 of a university school. The 40-items questionnaire was designed to identify, among the population of students quitting their programs, five categories or types of factors that potentially lead to students dropping out-Psychological, Sociological, Economic, Organizational and Integration-Adaptation-with their respective subcategories. Knowing the reasons why college students abandon an academic program in particular will allow university managers to analyze administrative and/or academic requirements and take mitigation measures to minimize college dropout.
\end{abstract}

\section{Keywords}

dropout, higher education, dropout models, standards, retention

\section{Introduction}

Student dropout is a complex phenomenon with many negative impacts for both the student and the school itself and by extension to the region and society in general (Rojas, 2009).

However, it is still perceived that the dropout definition is under discussion, although there is general consensus by defining it as a voluntary abandonment explained by different categories of variables, phenomena or factors, whether socioeconomic, individual, institutional and/or scholars (Peralta, 2008). 
According to Himmel (2002, p. 94), it is “(..) a premature abandonment of a curriculum before reaching the diploma or degree, and considered long enough to rule out the possibility that the student is reincorporated".

Regardless of conception, dropout has become a phenomenon of study (Braxton, Milem, \& Sullivan, 2000), as it has become a problem for the formal education system and results in a negative impact on social, economic, political and cultural processes, thereby constituting a risk according to the theory of Amartya Sen (Adducchio, Escobar, Larrosa, \& Salvio, 2012). This theory holds that the more highly qualified citizens there are from universities, the more freedom, more ethical understanding, empathy and higher social values that underpin a democratic society (Ristoff, 2001).

By considering university dropout as one of the factors that affects the accessibility and coverage of higher education, its measurement and study should be part of the continuous process of assessing the efficiency of the education system, the quality of the processes and programs offered by the institutions in order to establish academic and administrative mechanisms to control this phenomenon (Acosta, 2009; Arango, \& Ramírez, 2007; Cabrera, Bethencourt, Alvarez, \& González, 2006; Carvajal, Trejos, \& Caro, 2006; Donoso, S., Donoso, G., \& Arias, 2010).

The central purpose of this study focused first to design and validates a tool to determine the reasons why students drop out in their first years of college life and secondly implement the questionnaire in the field to verify the reason why students withdrawal from their university courses.

\subsection{Analysis Models}

Studies on student dropout have been approached from different angles and perspectives, according to the interests and needs of those who undertake them; however, in most of these studies, dropouts are associated with school failure (Muñoz, Rodrígez, Restrepo De Cepeda, \& Borrani, 2005).

In contrast, dropouts should be studied as the result of different factors that affect not only the student, but also its impact on the institutional context (Cordero, 2008), and approaches for study are analysis models supported by several studies (Jadue, 2002; Mares, Rocha, Rivas, Rueda, Cabrera, Tovar, \& Medina, 2012; Merlino, Ayllón, \& Escanés, 2011).

Thus, there are studies based on psychological models that address the problem from the individual perspective and the personality traits of the student as the cause for ending their studies due to the weakening of the initial intentions and the persistence of individual analysis (Lopera, 2008). On the other hand, in sociological analysis models, the influences of external factors to individual dropout (Díaz, 2008) are emphasized.

Another model of dropout analysis is presented by Vásquez and Rodríguez (2007), who argue that low economic resources that prevent a student continuing to the level of aspired study constitutes a cause of exogenous type dropouts. So the economic model adopts a cost/benefit approach that considers both a lack of resources to meet the expenses of college attendance as well as the need to work or seek employment (Beyer, 1998; Abril Valdez, Román, Cubillas, \& Moreno, 2008; Gessaghi \& Llinas, 2005; De Vries, León, Romero, \& Hernández, 2011). The model of organizational analysis focuses on the 
dropout from the characteristics of the university (Donoso \& Schiefelbein, 2007), based on the services they offer their students founded on the qualities of the educational organization, social integration among students and more particularly on the experiences of students in the classroom (Berger \& Milem, 1999). For this reason, to analyze student dropout it is necessary to know the determinants that affect it, which should include the variables considered relevant, to take into account the individuals' own characteristics, their home, their environment, and the educational institution; which in turn are supported by analysis models; as is shown in Figure 1.

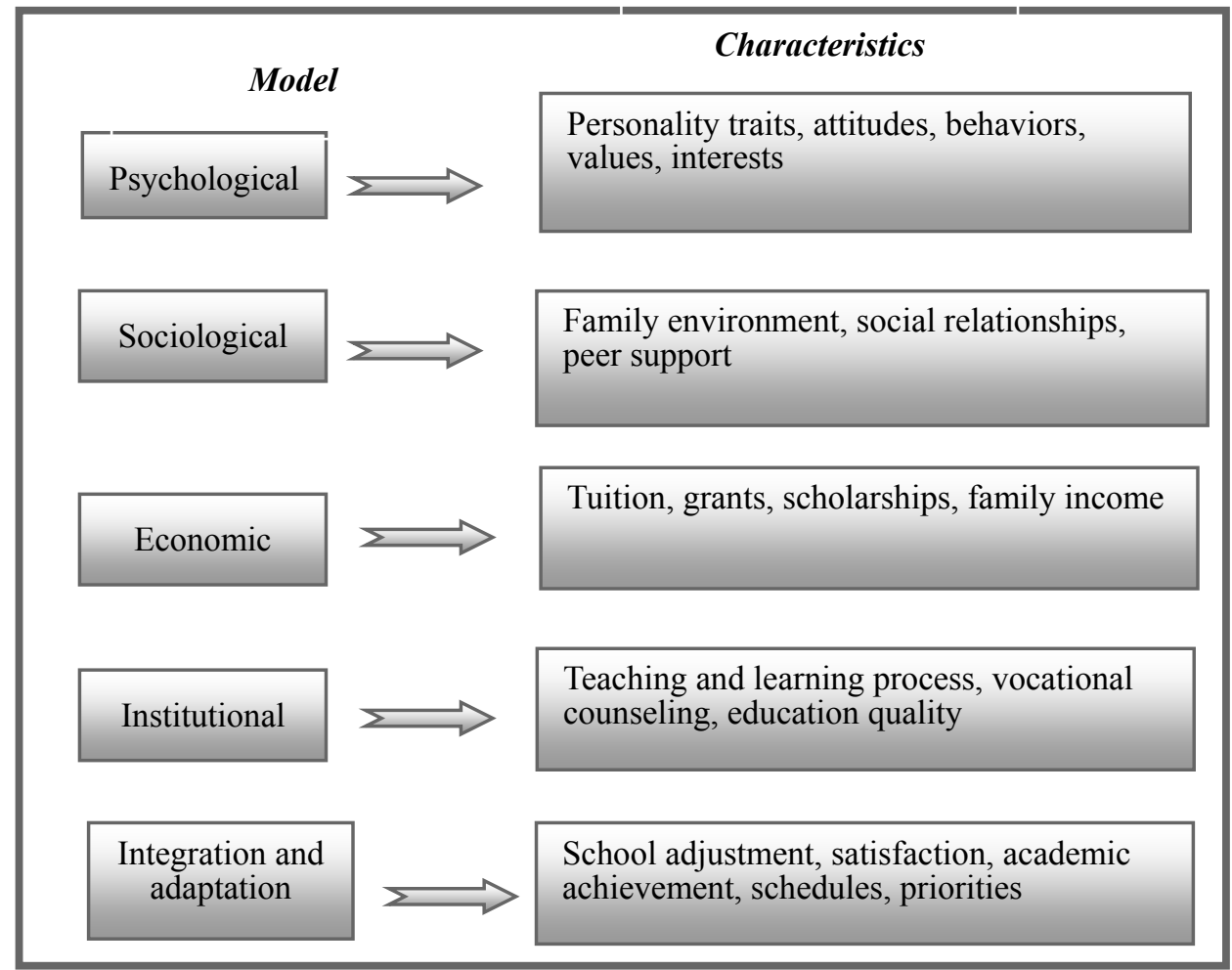

Figure 1. Conceptual Variables Identified in the Literature Review and Used in This Study as Possible Determinants of Dropout

Whatever the type of particular model of dropout used, Giuliodori, R. F., Giuliodori, M. A., and González (2004) note that to study the problem of dropout it is necessary to know the scale of it, that is, express it in a particular measurement to indicate in any case, the number of students who do not complete their studies within a defined period, resulting in a dropout rate. It is clear that higher education institutions should establish mechanisms to prevent, or at least, minimize dropout, and therefore must know the root causes. 


\section{Materials and Methods}

\subsection{Scope}

Of the models mentioned in the literature, the instrument was based on the statements of Braxton, Milem and Sullivan (2000), focusing only on the student dimension and not considering in their design either the dimension of the managers of administration or the dimension of academic tutors or relatives. In this research, the psychological, sociological, economic, organizational and integration-adaptation phenomenal categories were analyzed, as probable factors predicting university dropout; and were considered as those outlined in Figure 2.

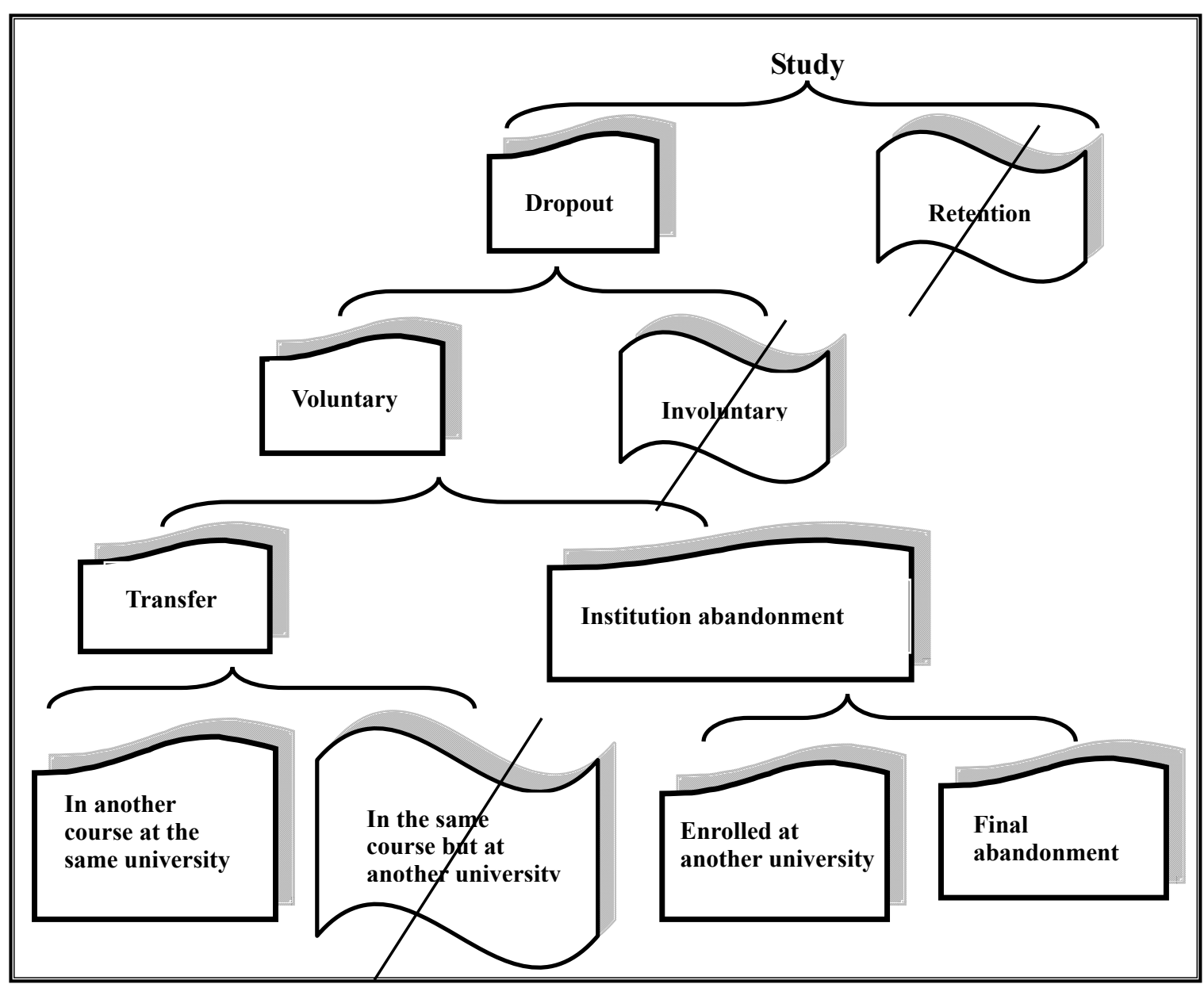

Figure 2. Outlining the Scope and Limits of the Types of Dropout Taken into Account in the Design of the CADES Instrument

Figure 2 refers, that in this studio were taken into consideration those aspects not deleted or crossed out, i.e., was not taken into account retention or involuntary dropout, or transfer to the same course of study, but in another different university.

\subsection{Population and Sample}

For the validation of the instrument, the student population enrolled in the first and second half of a Published by SCHOLINK INC. 
local public university in the years 2013, 2014 and 2015 was considered. The population who participated in the validation of the questionnaires was a dropout population made up of students who transferred to another course or another institution of higher education or simply abandoned their university studies voluntarily as a shown in Figure 2. The selection of the sample unit for the validation of the instrument ( $\mathrm{n}=114, \mathrm{p}=\mathrm{q}=50 \%$ and $95 \%$ confidence) used random cluster sampling without replacement elements. Dropout's students were enrolled in their first years of college, aged between 18 and 20 years. It is necessary to note that in this work, the type of genre of student leaver was not considered separately.

\subsection{Instrument Design}

For the study of the instrument design to determine the "model" followed in a given university dropout, the students withdrawal was directly analyzed, by the fact that the dropout dropping is a phenomenon inherent to student's life will surely be maintained a relationship with the dynamics in university management, academic performance and efficiency the educational system (Diaz, 2008). The questionnaire was designed as a self-report tool, using colloquial and simple language in the re-wording of the various statements in a total of 40 items.

\subsection{Instrument Validation}

For the assessment of the consistency, reliability and understandability (Tejedor \& Huerta, 2010), which is the "accuracy and precision of an instrument" (Piña-López, 2003; De La Peña, Patño, Mendizabal, Cortés, Cruz, Ulloa, ... Lara, 1998), the model of internal consistency, Cronbach's Alpha, based on the average of the correlations between items of the questionnaire, was used (Cortina, 1993; Schmitt, 1996). If the value of Cronbach's Alpha is closer to 1, the higher the internal consistency or understandability of the items that make up the assessment instrument analyzed (Nuviala, Tamayo, Iranzo, \& Falcón, 2008). To perform the validation of consistency of the instruments the field technique was used. The self-administered questionnaires were given to a sample of stakeholders randomly selected, and were filled in by them without the presence of the interviewer.

Participants were asked to rate the questions based on their understandability (Brockmann, Causadel, Homgren, Prado, Reyes, Viviani, \& Bertrand, 2007) using the following scale: item not understood at all $(=1)$; is not understood $(=2)$; neutral $(=3)$; it is understood $(=4)$ and is well understood $(=5)$ in order to establish a working scale (Cea, 2004; apud Martín Moreno, 2007). The time factor is not taken into consideration as a variable in the instrument reply.

Once the instrument's intelligibility was validated, we proceeded to apply it in the fieldwork; where first, a university was visited for the number of students prematurely leaving a particular faculty in the period 2013-2015.

Once students leavers were identified (defined as students who enrolled in the first half of their programs, but did not enroll in the same program in the next academic period), we proceeded to its location. To locate the selected students we resorted to "word of mouth" inquiry among classmates, for it was necessary to visit classrooms or groups where the said student, and potential leaver, had attended 
the first academic semester. Contact with student leavers was also made by sending e-mails or through contacts by social networks such as Facebook.

Despite the difficulties of delivery and collection of instruments, the commitments and responsibilities of each of the students who participated in the validation instruments was delivered personally or sent by e-mail, with subsequent collection thereof. To validate the reliability of the results or category variables they were parameterized by assigning numeric attributes on a scale of 1 (low impact) to 5 (much impact on decision to dropout). The descriptive and inferential statistics were used from the data obtained in the field to making decisions of inter or intra factors causing dropout.

\section{Results and Discussion}

\subsection{Construct Design}

In designing the instrument's construct, the proposals made in other studies, which served as a background for our instrument, were taken into consideration. However, from those studies, we consider only exogenous and endogenous aspects related solely to student dimension, ruling aspects of administrative management, among others, as presented in the Table 1.

\section{Table 1. Distribution of Factors, Criteria and Sub-Factors Listed in Instrument Design Construct}

\begin{tabular}{|c|c|c|}
\hline Factors & Criteria & Sub-factors \\
\hline Psychological & $\begin{array}{l}\text { Personality traits, intentionality, } \\
\text { Perception and Analysis of university } \\
\text { life, Values and expectations of success } \\
\text { in college, Support received from the } \\
\text { family. }\end{array}$ & $\begin{array}{l}\text { Personality, beliefs, attitudes, } \\
\text { behaviors, personal attributes, } \\
\text { family support, norms values and } \\
\text { interests, and persistence. }\end{array}$ \\
\hline Sociological & $\begin{array}{l}\text { Group integration. Family atmosphere. } \\
\text { Social media. }\end{array}$ & $\begin{array}{l}\text { Family environment, social } \\
\text { relations, social environment, peer } \\
\text { support and expectations. }\end{array}$ \\
\hline Economic & $\begin{array}{l}\text { Scholarships and economic benefits } \\
\text { associated with the studies. } \\
\text { Ability to cover the college expenses. } \\
\text { College grants. }\end{array}$ & $\begin{array}{l}\text { Tuition fees, grants, scholarships } \\
\text { and family income. }\end{array}$ \\
\hline Organizational & $\begin{array}{l}\text { Teaching strategies: motivation and } \\
\text { guidance. } \\
\text { Vocational guidance services of the } \\
\text { institution. } \\
\text { Existence of complementary activities. }\end{array}$ & $\begin{array}{l}\text { Teachers and administrative } \\
\text { consultations, teaching staff, } \\
\text { vocational guidance, extra } \\
\text { activities, quality of education } \\
\text { received. }\end{array}$ \\
\hline Adaptation and integration & Cultural and educational levels of & Efforts, rewards, interaction, \\
\hline
\end{tabular}


families.

Personal attributes and pre-college experiences.

Development activities between peers and teachers.

Participation in extracurricular

activities. adaptation, student commitments, emotional state, levels of satisfaction, achievement, aspirations, accessibility, class schedules, personal priorities.

\subsection{Validation of Reliability}

In validating the understandability of the instrument consisting of 40 items, involving a total of 50 individuals; of which 40 (80\%) responded completely.

Once subjected to the validation phases, it was possible to determine the overall internal consistency of the instrument, resulting in a value of Cronbach's Alpha coefficient of 0.91. Once questionnaire intelligibility was validated, we proceeded to the randomization of items associated with each of the five factors as presented in the Table below.

Table 2. Distribution of Items by Factors for the Instrument Designed

\begin{tabular}{|c|c|c|c|}
\hline Factor & Item number & $\begin{array}{l}\text { Number of } \\
\text { items }\end{array}$ & $\begin{array}{l}\text { Cronbach's } \\
\text { Alpha }\end{array}$ \\
\hline Psychological & $3-4-6-7-11-13-14-19-34$ and 40 & 10 & 0.89 \\
\hline Sociological & $2-9-15-16$ and 17 & 5 & 0.87 \\
\hline Economic & $8-22-23-24-25$ and 27 & 6 & 0.95 \\
\hline Organizational & $18-21-28-29-30-31-32$ and 33 & 8 & 0.92 \\
\hline Adaptation and integration & $1-5-10-12-20-26-35-36-37-38$ and 39 & 11 & 0.92 \\
\hline TOTAL & & 40 & $0.91 *$ \\
\hline
\end{tabular}

*Global Cronbach's Alpha.

Taking into consideration the statements given by Maller (1995; apud Nuviala et al., 2008) who indicates that if the Cronbach's Alpha is greater than 0.9 the measuring instrument is excellent; in the range of 0.9 to 0.8 the instrument is good; between from 0.8 to 0.7 the instrument is acceptable; in the range between 0.7 to 0.6 the instrument is weak; between 0.6 to 0.5 the instrument is poor; and if less than 0.5 is not acceptable; it is concluded that the questionnaire as an instrument to determine the factors associated with college dropout reveals its excellent level of understandability for which it was designed.

\subsection{Implementation of the Instrument}

CADES tool was developed to predict which of the 5 factors see Table 1 and 2 identified in the 
literature and contemplated in its design, emphasized more in the dropout manifested by students. Once the assessment phase of the understandability of the instrument and made recommendations arising from this phase, we proceeded to the actual implementation of CADES.

The implementation of the instrument was performed on a dropout population- $30 \%$ males and $70 \%$ females_-from a local university for the years 2013, 2014 and 2015.

As a mentioned before, the type of genre of student leaver was not considered separately, however, some research studies, such as those made by Molina; Ferrada, Pérez, Casanueva and Gracia (2004) point out that adolescent pregnant students and single women are most likely to drop out of education systems, when compared to men.

Below are, first, the results derived from the implementation of the questionnaire, analyzing each factor, and second, contextualizing the instrument to the overall analysis of the 5 factors associated with dropping out attempting to identify what type of model was followed by the dropout population studied.

Considering that the five factors of dropout, its were scattered among the 40 items of CADES, as shown in Table 2. From the analysis of the data obtained in the field, it was possible to group the items by factors to analyze its higher or lower incidence in the dropout manifested as presented in the following paragraphs.

\subsubsection{Psychological Factor}

To assess the psychological factor, specifically the personality traits and their impact on dropout, an analysis of variance single factor for simultaneous sub-factors (f Fisher) for a reliability coefficient of 0.05 ( $p<0.05$ was used) was carried out where it determined that $f_{\text {cal }}$. $(15.18)$ was higher than $f_{\text {teo. }}(2.02)$ for an alpha $(\alpha)$ of 0.05 ; which is indicative that the eight sub-factors including the psychological factor have a significant impact on differentiated dropout, which follow the incidence following behavior:

Values- and interests (Rules) $>$ Behaviors $>$ Support $>$ Persistence $>$ Belief $>$ Attitudes $>$ Personality $>$ Attributes.

This observed distribution related to the sub-factor values and interests-rules-is the one that seems to have influenced the phenomenon of dropout expressed by the students. That is, the student dropping out considers that the values, laws, interests, regulations, and the social and academic regulations that apply in college in reality do not conform to their perception of university life before entering college, which is why the student feels "disoriented" in the enrolled courses and leaves.

\subsubsection{Sociological and Economic Factors}

In the sociological factor, 4 sub-factors where the influence as an external factor to students analyzed are considered.

Applied statistical analysis could not detect significant differences between the sub-factors studied, i.e., social relations among students and between teachers, peer support and expectations of students influenced in equal "proportion" in the dropout observed.

Under this concept, it is suggested that dropout is the result of the lack of integration of students to the 
university educational environment and social integration mainly affects student satisfaction in their participation in the educational organization, and it is helpful for the university to reaffirm its institutional commitment, as mentioned previously.

The designed and implemented questionnaire could also demonstrate that the economic factor and three sub-factors, i.e., tuition costs, grants or scholarships and family income influenced the "magnitude" of student dropout. The literature refers to the economic factor being closely associated with student dropout; by the fact that often the student experiences economic difficulties in meeting the basic needs of food, transportation, lodging, among other difficulties. In this sense, Sanabria (2002) argues that often the economic factor is decisive, even to the choice of a particular course.

\subsubsection{Organizational Factor}

The organizational factor focuses on dropout from the characteristics of the university, social integration among students in the classroom, to inquiries from students and vocational guidance received. Performing the statistical analysis it was verified that for the organizational factor; five sub-factors differentially affect the dropout studied, suggesting the following order of incidence:

Academic support activities $>$ Consulting $>$ Career $>$ Teaching Orientation $>$ Quality of education.

\subsubsection{Adaptation and Integration Factor}

As mentioned above, the adaptation and integration factor tries to explain that dropout occurs depending on the qualities of universities in terms of social integration among peers and between teachers-students.

When considering average responses sub-factors values, and applying statistical analysis, it was determined that for the adaptation and integration factor their sub-factors differentially affect dropout, as shown in the following sequence:

Adaptation $>$ Access $>$ Schedule $=$ Emotional state $=>$ Satisfaction $>$ Aspirations $>$ Priorities $>$ Interaction $>$ Effort.

It should be emphasized that the inadequate adaptation of students to their new role within the university environment was a decisive factor for abandoning their studies at the end of the first half of the selected course.

Similar findings were reported by Yengle (2009), who believes that the difficulty in adapting to university student life, during the first terms, is an essential factor associated with dropout.

The university has a central role, as regards the adaptation of young people to their new student life as they remain in institutions, where they adapt and benefit from the services and opportunities that are offered.

\subsubsection{CADES and Dropout Type}

The instrument designed was titled CADES and was developed with the purpose of serving as an analytical tool to determine the existence of a pattern type or model followed by students dropping out of a given university.

Which is why, when analyzing the results of the survey field data in the dropout population and based 
on the null hypothesis, where CADES was not able to identify a particular type of model dropout, analysis was performed variance of one factor for simultaneous sub-factors (f Fisher), as shown in Table 3; and it was determined that $f_{\text {cal }}(21.73)$ was greater than the $f_{\text {teo }}(2.38)$ to an alpha $(\alpha)$ of 0.05 ; proving that the dropout of students from a university academic unit, followed indeed a typical pattern of behavior.

Table 3. F Fisher Test (ANOVA) for Analysis of Dropout Student's Type

\begin{tabular}{|c|c|c|c|c|}
\hline Factors & Average & & Variance & \\
\hline Psychological & 1.98 & & 1.65 & \\
\hline Sociological & 1.80 & & 1.28 & \\
\hline Economic & 2.59 & & 2.53 & \\
\hline Organizational & 2.21 & & 1.92 & \\
\hline Adaptation and integration & 2.00 & & 1.76 & \\
\hline Origin of variations & $\begin{array}{l}\text { Sum of } \\
\text { square }\end{array}$ & $\begin{array}{l}\text { Degree of } \\
\text { freedom }\end{array}$ & $f_{\text {cal }}$ & $f_{\text {teo }}$ \\
\hline Among the sub-factors & 158.46 & 4 & & \\
\hline Within the sub-factors & 5090.30 & 2793 & 21.73 & 2.38 \\
\hline Total & 5248.76 & 2797 & & \\
\hline
\end{tabular}

In this regard, the global average values to responses obtained were taken into consideration and ordered from highest to lowest average, the order of incidence of the 5 factors follows the following distribution:

Economic $>$ Organizational $>$ Adaptation and Integration $>$ Psychological $>$ Sociological.

Therefore, it is interpreted that the dropout manifested by students studied tends to behave according to the Economic Type. This means that the main reasons that led students to drop out of their courses are primarily economic.

We could observe in our study, that economic situation of students and therefore the economic status of their parents correlate with the dropout, as it was also reported in other studies (Aranque, Roldán, \& Salguero, 2009). Some family economic difficulties or the lack of financial help for studying force some students to simultaneously study and work which some cases induces situations of incompatibility that cause dropout.

This shows that the CADES tool allowed define the model of dropout analyzed. Of the three theoretical models reported in the literature to identify a particular type of dropout, that is, Tinto's Student Integration Model (1975), the College Choice Model Nexus (St. John, Hu, \& Weber, 2001; apud Schatzel, Callahan, \& Davis, 2013) and the Bean's Student Attrition Model (1980), the recognized Economic Type, identified with CADES tool, is part of the first two. According to these theoretical 
models, the economic status of the students' parents, among other additional factors, influence firstly, directly in student engagement in order to continue in a college course and the goal of graduating, and secondly instead, the choice of a university in particular.

\section{Conclusions}

Currently, university offers students different experiences that help them to define their life plan, besides representing an indispensable social learning and personal development aspect. For the above and in reference to the design and validation of the CADES instrument to determine the causes for student dropout, we conclude the following:

1) The validations performed on the CADES instrument, including the overall internal consistency—understandability levels and ability to identify dropout model—proved to be successful and bring out the excellent parametric properties for which the questionnaire was designed.

2) By implementing the CADES in a dropout population, it was possible to identify the "model" whereby students dropped out in their first years of university life, the economic model having the greatest impact on the dropout rate.

\section{References}

Abril, V. E., Román, P. R., Cubillas, R. M. J., \& Moreno, C. I. (2008). Deserción o autoexclusión? Un análisis de las causas de abandono escolar en estudiantes de educación media superior en Sonora, México. Revista Electrónica de Investigación Educativa, 10(1), 1-16.

Acosta, M., \& del S. (2009). Los procesos de aprendizaje y su incidencia en la deserción estudiantil en el Programa de Química Farmacéutica de la Universidad de Cartagena. Psicología desde el Caribe, 24, 26-58.

Adducchio, S. P., Escobar, P. M., Larrosa, J. M., \& Salvio, M. J. (2012). Proyecto Mutual de Crédito Universitario (p. 82). Buenos Aires: Universidad Nacional de La Matanza.

Arango, Z. M. M., \& Ramírez, M. D. M. (2007). Análisis desde la Teoría Motivacional de las causas de ingreso y deserción del estudiante universitario. Scientia et Technica, 13(37), 389-394.

Aranque, F., Roldán, C., \& Salguero, R. (2009). Factors influencing university dropout rates. Computer \& Education, 53, 563-574.

Bean, J. P. (1980). Dopouts and turnover. The synthesis and test of a causal model of student attrition. Research in Higher Education, 12(2), 155-187.

Berger, J. B., \& Milem, J. F. (1999). The role of student involvement and perceptions of integration in a causal model of student persistence. Research in Higher Education, 40(6), 641-664.

Beyer, H. (1998). Desempleo juvenil o un problema de deserción escolar? Estudios Públicos, 71, 89-119.

Braxton, J. M., Milem, J. F., \& Sullivan, A. (2000). The influence of active learning on the college student departure process. The Journal of Education, 71(5), 569-590. 
Brockmann, R., Caussadel, S., Holmgren, N. L., Prado, F., Reyes, B., Viviani, P., \& Bertrand, P. (2007). Actividad física y obesidad en niños con asma. Revista Chilena de Pediatría, 78(5), 482-488.

Cabrera, L., Bethendourt, J. T., Álvarez, P. P., \& González, M. (2006). El problema del abandono de los estudios universitarios. Revista Electrónica de Investigación y Evaluación Educativa, 12(2), 171-203.

Carvajal, O. P., Trejos, C. A. A., \& Caro, I. C. A. (2006). Estudio de causas de deserción de los estudiantes de la Universidad Tecnológica de Pereira enero/2000—Diciembre/2004 utilizando la técnica de análisis de correspondencias simples. Scientia Et Technica, 12(30), 261-266.

Cordero, C. T. (2008). La opinión de un grupo de docentes sobre la deserción escolar. Explorando sobre sus actuaciones en el contexto institucional. Revista Electrónica Actualidades Investigativas en Educación, 8(3), 1-33.

Cortina, J. M. (1993). What is coefficient alpha? An examination of theory and applications. Journal of Applied Psychology, 78(1), 98-104.

De La Peña, F., Patiño, M., Mendizabal, A., Cortés, J., Cruz, E., Ulloa, R. E., ... Lara, M. C. (1998). La entrevista semiestructurada para adolescentes (ESA): Características del instrumento y estudio de confiabilidad interevaluador y temporal. Salud Mental, 21(6), 11-18.

De Vries, W., León, A. P., Romero, M. J. F., \& Hernández, S. I. (2011). Desertores o decepcionados? distintas causas para abandonar los estudios universitarios. Revista de la Educación Superior, 40(160), 29-50.

Díaz, P. C. (2008). Modelo conceptual para la deserción estudiantil universitaria chilena. Estudios Pedagógicos, 34(2), 65-86.

Donoso, S., Donoso, G., \& Arias, Ó. (2010). Iniciativas de retención de estudiantes en educación superior. Revista Calidad en la Educación, 33, 15-61.

Donoso, S., \& Sschiefelbein, E. (2007). Análisis de los modelos explicativos de retención de estudiantes en la universidad: Una visión desde la desigualdad social. Estudios Pedagógicos, 33(1), $7-27$.

Gessabhi, V., \& Llinás, P. (2005). Democratizar el acceso a la educación superior. Buenos Aires, Argentina: Centro de Implementación de Políticas Públicas para el Equidad y el Crecimiento CIPPEC (p. 31).

Giuliodori, R. F., Giuliodori, M. A., \& González, M. (2004). La deserción en el nivel medio de la educación en la Republica Argentina. Cálculo de tasas de abandono e identificación de algunos factores que se le asocian. Revista de Economía y Estadística, 42, 71-92.

Himmle, E. (2002). Modelos de análisis de la deserción estudiantil en la educación. Calidad en la Educación (pp. 91-108).

Jadue, G. (2002). Factores psicológicos que predisponen al bajo rendimiento, al fracaso y a la deserción escolar. Estudios Pedagógicos, 28, 193-204.

Lopera, O. C. (2008). Determinantes de la deserción universitaria en la Facultad de Economía Published by SCHOLINK INC. 
Universidad del Rosario. Borradores de Investigación, 95, 1-25.

Mares, G., Rocha, H., Rivas, O., Rueda, E., Cabrera, R., Tovar, J., \& Medina, L. (2012). Identificación de factores vinculados con la deserción y la trayectoria académica de los estudiantes de psicología en Iztacala. Enseñanza e Investigación en Psicología, 17(1), 189-207.

Martín, M. C. (2007). Metodología de investigación en estudios de usuarios. Revista General de Información y Documentación, 17(2), 129-149.

Merlino, A., Ayllón, S., \& Escanés, G. (2011). Variables que influyen en la deserción de estudiantes universitarios de primer año: Construcción de índices de riesgo de abandono. Actualidades Investigativas en Educación, 1(2), 1-30.

Molina, M., Ferrada, N. C., Pérez, R., Cid, L., Casanueva, V., \& García, A. (2004). Embarazo en la adolescencia y su relación con la deserción escolar. Revista Médica de Chile, 132, 65-70.

Muñoz, I. C., Rodríguez, P. G., Restrepo, De Cepeda, P., \& Borrani, C. (2005). El síndrome del atraso escolar y el abandono del sistema educativo. Revista Latinoamericana de Estudios Educativos, $35(3-4), 221-285$.

Nuviala, A., Tamayo, J. A., Iranzo, J., \& Falcón, D. (2008). Creación, diseño, validación y puesta en práctica de un instrumento de medición de la satisfacción de usuarios de organizaciones que prestan servicios deportivos. Revista Nuevas Tendencias en Educación Física, Deporte y Recreación, 14, 10-16.

Piña-López, J. A. (2003). Validación de un instrumento para medir competencias conductuales en personas VIH positivas. Salud Pública de México, 45(4), 293-297.

Ristoff, D. I. (2001). O exame nacional de curso e a avaliação institucional. Avaliação: Revista da Rede de Avaliação da Educação Superior, 6(3), 21-29.

Rojas, M. (2009). El abandono de los estudios: deserción y decepción de la juventud. Hologramática, $6(1), 75-94$

Sanabria, H. (2002). Deserción en estudiantes de enfermería en cuatro universidades del Perú. Revista Educativa Anales de la Facultad de Medicina, 63(4), 301-311.

Schatzel, K., Callahan, T., \& Davis, T. (2013). Hitting the books again: Factors influencing the intentions of young adults to reenroll in college. Journal of College Student Retention, 15(3), 345-365.

Schmitt, N. (1996). Uses and abuses of coefficient alpha. Psychological Assessment, 8(4), 350-353.

Tejedor, De Leon, A., \& Huerta, J. M. (2012). The Balance Store Card for the Design and Validation Instruments to Measure the Academic Teacher's Achievement and Performance. Education, 2(7), 220-206.

Tinto, V. (1975). Dropout from higher education: A theoretical synthesis of recent research. Review of Educational Research, 45(1), 89-125

Vásquez, M. C. R., \& Rodríguez, P. M. C. (2007). La deserción estudiantil en educación superior a distancia: Perspectiva teórica y factores de incidencia. Revista Latinoamericana de Estudios 
Educativos, 37(3-4), 107-122. 